\title{
Analisis Media Pembelajaran Online Pada Masa Pandemi Covid-19 Menggunakan Metode System Usability Scale
}

\author{
Eva $^{1}$, Widya Cholil ${ }^{2}$ \\ 1,2 Program Studi Sistem Informasi, Universitas Bina Darma, Palembang, Idnonesia \\ Email: evaaaa29juli@gmail.com ${ }^{1}$, widya@binadarma.ac.id ${ }^{2}$
}

\begin{abstract}
Abstrak
Adanya pandemi saat ini yang melanda banyak kota-kota di indonesia menyebabkan timbul masalah baru pada semua aspek Khususnya disektor pendidikan memberlakukan anjuran belajar dari rumah atau dikenal dengan Study from Home (SFH). Untuk siswa SMP (Sekolah Menengah Pertama) dimana siswa-siwa tersebut jarang bahkan ada yang belum pernah menggunakan media belajar online dan di tuntut untuk menggunakan media pembelajaran online. Menarik untuk dikaji, sejauh mana kualltas media pembelajaran online yang telah di selenggarakan beberapa bulan ini untuk siswa SMP (Sekolah Menengah Pertama). Penelitian ini mengambil sampel 100 siswa SMP Provinsi Sumatera Selatan dengan menggunakan metode SUS (System Usability Scale) Untuk mengetahui kepuasan penggunaan media belajar online dengan pengujian usabilitas sebuah aplikasi. Dari hasil kuisioner yang telah di sebar dan di analisis oleh peneliti maka di dapat kesimpulan bahwa media yang paling banyak di gunakan siswa SMP di Sumatera Selatan pada masa pandemi covid -19 ini adalah Google Classroom dimana dari 100 sampel yang memilih media google classroom ini sebanyak 73 Siswa dengan penilaian medianya mendapatkan skor 63,6644 dengan grade D. Tetapi Google Classroom ini bukan media yang mendapatkan nilai skor terbaik. Menurut penelitian di atas media yang mendapatkan nilai skor terbaik yaitu media pembelajaran Edmodo mendapatkan nilai SUS sebesar 78,5 dengan grade C (acceptable). Sedangkan untuk media pembelajaran Zoom mendapatkan nilai skor 70,4 dengan grade C dari 7 Responden dan Media Pembelajaran Google Meet mendapatkan nilai Skor SUS 55,3 dengan grade E dari 8 responden.
\end{abstract}

Kata Kunci : Analisis media, Pembelajaran, Online, System Usability Scale

\section{PENDAHULUAN}

Musim covid19 pada hari ini belum juga mengalami penurunan grafik jumlah pasien, total kasus pertama yang terkena corona ini di indonesia hanya 2 orang. (Debora, 2020). Dengan seiringnya waktu Dari tanggal tersebut jumlah pasien covid terus bertambah sehingga berbagai kegiatan telah di upayakan 


\section{Journal of Software Engineering Ampera}

Vol. 2, No. 3, October 2021 e-ISSN: 2775-2488

https://journal-computing.org/index.php/journal-sea/index

pemerintah untuk mengurangi jumlah pasien yang terkena corona atau lebih dikenal Covid19. Adanya pandemi covid19 masa sekarang yang melanda banyak kota-kota di indonesia menyebabkan banyak timbul masalah baru pada semua bidang baik dibidang pemerintahan, ekonomi, politik, sosial dan budaya, Khususnya dibidang pendidikan memberlakukan aturan belajar online atau belajar di rumah. hal ini tentunya menjadi sesuatu yang baru dalam bidang pendidikan di indonesia, karena banyak sekolah yang belum pernah menjalankan belajar online atau daring. pada musim corona ini metode pembelajaran online adalah metode yang di gunakan agar proses belajar mengajar tetap efektif dan bisa berjalan seperti biasanya walau tanpa tatap muka langsung.

TIK saat ini menjadi wadah untuk mengcangkup segala kelengkapan teknisi untuk mengolah serta memberikan suatu informasi kepada siswa. TIK memilki 2 aspek ialah informasi dan komunikasi. Teknologi informasi berupa seluruh perihal yang terkait dengan suatu alat bantu, proses, dan manipulasi, serta untuk mengelola data menjadi informasi. Dan sebaliknya teknologi komunikasi ialah segala hal berkenaan dalam alat untuk membantu memproses dan memberikan informasi ke fitur satu dan kemudian ke fitur yang lain. (Budiman, 2017). TIK ini merupakan media belajar online untuk mengatasi kelemahan-kelemahan dalam proses belajar mengajar khususnya pada masa pandemi (Miftah \& sari, 2020).

Tegnologi sistem informasi belajar yang efektif dan mudah juga sangat di butuhkan oleh siswa terutama siswa SMP, karena berhubungan dengan aktivitas yang di lakukan seperti biasanya di luar rumah membuat siswa-siswa akan merasa malas dikarenakan semua aktivitas di outdoor akan di larang. seperti loakasi liburan dan lokasi biasa mereka bercanda dengan kawankawan sepermainannya di sekolah.

Oleh karena itu di era digital sekarang ternologi informasi bersaing untuk mengeluarkan sistem infomasi berupa aplikasi yang canggih, mudah dan

inovatif untuk memotivasi dan menunjang media belajar online pada masa pandemi. Khusunya untuk siswa SMP dimana siswa-siwa tersebut jarang bahkan ada yang belum pernah menggunakan media belajar online dan di tuntut untuk menggunakan media pembelajaran online. Untuk mengetahui kepuasan pada penggunaan media belajar online peneliti menggunakan metode System Usability Scale (SUS). Dimana Metode SUS merupakan cara untuk melakukan penelitian usabilitas sebuah aplikasi. Instrumen pada 


\section{Journal of Software Engineering Ampera}

Vol. 2, No. 3, October 2021 e-ISSN: 2775-2488

https://journal-computing.org/index.php/journal-sea/index

pengujian mengguanakan kuesioner yang terdiri 10 pernyataan yang di manfaatkan untuk pengukuran usability atau kepuasan media pembelajaran online dengan perspektif subjektif siswa. Berdasarkan latar belakang di atas, peneliti menganalisis media yang banyak di gunakan untuk media pembelajaran online dengan judul Analisis Media Pembelajaran Online Pada Masa Pandemi Covid-19 Menggunakan Metode SUS (System Usability Scale).

\section{METODE PENLITIAN}

Penelitian ini merupakan jenis penelitian kuantitatif dengan pendekatan deskriptif yang perhitungannya menggunakan metode SUS (System Usability Scale) untuk mengetahui media pembelajaran online apa yang di gunakan pada masa pandemi covid-19 pada siswa SMP (Sekolah Menegah Pertama) di Provinsi Sumatera Selatan.

\subsection{METODE SYSTEM USABILITY SCALE}

Metode uji System Usability Scale (SUS) adalah yang dikembangkan oleh John pada tahun 1986 dan mempekerjakan pengguna akhir dalam penelitiannya. Teknik SUS untuk penelitian ini memiliki beberapa keunggulan: responden akan lebih memahami proses evaluasi, aplikasi yang sering digunakan akan terlihat lebih jelas, dan prosedur penelitian dengan responden akan dimudahkan dengan penggunaan 10 instrumen pertanyaan.

Table 1. Instrumen System Usability Scale

\begin{tabular}{|l|l|l|}
\hline No & \multicolumn{1}{|c|}{ Pernyataan } & Nilai \\
\hline 1 & $\begin{array}{l}\text { saya akan menggunakan media pembelajaran ini secara } \\
\text { teratur. }\end{array}$ & $1-5$ \\
\hline 2 & $\begin{array}{l}\text { Saya pikir media pembelajarannya terlalu rumit untuk di } \\
\text { gunakan. }\end{array}$ & $1-5$ \\
\hline 3 & $\begin{array}{l}\text { Saya menemukan media pembelajaran yang mudah } \\
\text { digunakan. }\end{array}$ & $1-5$ \\
\hline 4 & $\begin{array}{l}\text { Untuk menggunakan media pembelajaran ini, saya yakin } \\
\text { saya akan memerlukan bantuan dari orang teknis. }\end{array}$ & $1-5$ \\
\hline 5 & $\begin{array}{l}\text { Banyak fungsi media pembelajaran ini terintegrasi dengan } \\
\text { baik, menurut saya. }\end{array}$ & $1-5$ \\
\hline
\end{tabular}




\section{Journal of Software Engineering Ampera}

Vol. 2, No. 3, October 2021 e-ISSN: 2775-2488

https://journal-computing.org/index.php/journal-sea/index

\begin{tabular}{|l|l|l|}
\hline 6 & $\begin{array}{l}\text { Saya yakin media pembelajaran ini mengandung terlalu } \\
\text { banyak ketidakteraturan. }\end{array}$ & $1-5$ \\
\hline 7 & $\begin{array}{l}\text { Kebanyakan individu, saya yakin, akan segera memahami } \\
\text { cara menggunakan media pembelajaran ini. }\end{array}$ & $1-5$ \\
\hline 8 & $\begin{array}{l}\text { Saya menemukan bahwa media pembelajaran ini cukup } \\
\text { sulit untuk digunakan. }\end{array}$ & $1-5$ \\
\hline 9 & $\begin{array}{l}\text { Saya cukup nyaman menggunakan media pembelajaran } \\
\text { ini. }\end{array}$ & $1-5$ \\
\hline 10 & $\begin{array}{l}\text { Sebelum saya dapat menggunakan media pembelajaran } \\
\text { ini, saya perlu belajar banyak hal. }\end{array}$ & $1-5$ \\
\hline
\end{tabular}

Instrumen SUS terdiri dari sepuluh pertanyaan, masing-masing dengan skor 1 sampai 5 . 1 berarti responden sangat tidak setuju, 2 berarti responden tidak setuju, 3 berarti responden setuju, 4 berarti responden setuju, dan 5 berarti responden sangat setuju. Menetapkan bobot untuk setiap item, skor SUS akan bervariasi dari 0 hingga 4 sesuai dengan aturan berikut :

a. Bobot dihitung dengan menghilangkan 1 untuk setiap skor yang diperoleh (Ganjil - 1) untuk item pernyataan bernomor ganjil $(1,3,5,7,9)$.

b. Kurangi 5 dari skor yang diperoleh untuk item pernyataan bernomor genap $(2,4,6,8,10)$. (5 - Genap).

c. Kalikan jumlah total dengan 2,5 .

Rumus untuk menghitung skor SUS untuk setiap responden dapat dinyatakan sebagai berikut secara sistematis:

Skor Responden $=((P 1-1)+(5-P 2)+(P 3-1)+(5-P 4)+(P 5-1)+(5-P 6)$ $+(P 7-1)+(5-P 8)+(P 9-1)+(5-P 10)) * 2.5)$

Setelah menemukan hasil untuk setiap responden, gunakan persamaan untuk menghitung rata-rata skor semua responden untuk mendapatkan skor SUS keseluruhan (1) :

\section{Nilai rata-rata $=\sum_{i=0}^{n} x i / N$ \\ Jimana $\mathrm{xi}$ : nilai score responden $\mathrm{N}$ : Jumlah Responden \\ Gambar 1. Rumus Perhitungan SUS}




\section{Journal of Software Engineering Ampera}

Vol. 2, No. 3, October 2021 e-ISSN: 2775-2488

https://journal-computing.org/index.php/journal-sea/index

Setelah menentukan skor SUS, tahap selanjutnya adalah menentukan penilaian yang selanjutnya diinterpretasikan dengan berbagai cara, antara lain:

Table2. Score SUS (System Usability Scale)

\begin{tabular}{|c|c|c|}
\hline Nilai & Grade & Range \\
\hline $0-50$ & F & Not Acceptable \\
\hline $51-60$ & E & Marginal Low \\
\hline $61-70$ & D & Marginal High \\
\hline $71-80$ & C & Acceptable \\
\hline $81-90$ & B & Acceptable \\
\hline $91-100$ & A & Acceptable \\
\hline
\end{tabular}

\subsection{Uji Validitas Dan Realibilitas}

Validitas dan reliabilitas kuesioner penelitian ditentukan dengan menggunakan uji validitas dan reliabilitas. Metode korelasi produk momen akan digunakan dalam uji validitas, dan Cronbach's Alpha akan dihitung dalam uji reliabilitas.

\section{HASIL DAN PEMBAHASAN}

Setelah kuisioner di sebarkan, maka peneliti melakukan pengelolaan data untuk di analisis. Berdasarkan hasil pengumpulan data menunjukkan bahwa kuisioner yang di bagikan sebanyak 10 pertanyaan untuk 100 orang siswa SMP agar semua layak di analisis sehingga tingkat respon rate $100 \%$.

Table3. Jenis Kelamin

\begin{tabular}{|c|c|c|c|c|c|}
\hline & & Frequency & Percent & Valid Percent & $\begin{array}{c}\text { Cumulative } \\
\text { Percent }\end{array}$ \\
\hline \multirow[t]{3}{*}{ Valid } & Laki-laki & 52 & 52.0 & 52.0 & 52.0 \\
\hline & Perempuan & 48 & 48.0 & 48.0 & 100.0 \\
\hline & Total & 100 & 100.0 & 100.0 & \\
\hline
\end{tabular}

Responden laki-laki merupakan mayoritas responden, terhitung 52 orang atau $52 \%$ pada tabel di atas. Responden perempuan berjumlah 48 orang, atau $48 \%$ dari total 100 responden. 


\section{Journal of Software Engineering Ampera}

Vol. 2, No. 3, October 2021 e-ISSN: 2775-2488

https://journal-computing.org/index.php/journal-sea/index

Tabel 4. Asal Sekolah

\begin{tabular}{|c|c|c|c|c|c|}
\hline & & Frequency & Percent & Valid Percent & Cumulative Percent \\
\hline Valid & Sekolah 1 & 16 & 16.0 & 16.0 & 16.0 \\
\hline & Sekolah 2 & 17 & 17.0 & 17.0 & 33.0 \\
\hline & Sekolah 3 & 10 & 10.0 & 10.0 & 43.0 \\
\hline & Sekolah 4 & 4 & 4.0 & 4.0 & 47.0 \\
\hline & Sekolah 5 & 6 & 6.0 & 6.0 & 53.0 \\
\hline & Sekolah 6 & 1 & 1.0 & 1.0 & 54.0 \\
\hline & Sekolah 7 & 3 & 3.0 & 3.0 & 57.0 \\
\hline & Sekolah 8 & 9 & 9.0 & 9.0 & 66.0 \\
\hline & Sekolah 9 & 5 & 5.0 & 5.0 & 71.0 \\
\hline & Sekolah 10 & 16 & 16.0 & 16.0 & 87.0 \\
\hline & Sekolah 11 & 3 & 3.0 & 3.0 & 90.0 \\
\hline & Sekolah 12 & 1 & 1.0 & 1.0 & 91.0 \\
\hline & Sekolah 13 & 1 & 1.0 & 1.0 & 92.0 \\
\hline & Sekolah 14 & 1 & 1.0 & 1.0 & 93.0 \\
\hline & Sekolah 15 & 1 & 1.0 & 1.0 & 94.0 \\
\hline & Sekolah 16 & 1 & 1.0 & 1.0 & 95.0 \\
\hline & Sekolah 17 & 1 & 1.0 & 1.0 & 96.0 \\
\hline & Sekolah 18 & 3 & 3.0 & 3.0 & 99.0 \\
\hline & Sekolah 19 & 1 & 1.0 & 1.0 & 100.0 \\
\hline & Total & 100 & 100.0 & 100.0 & \\
\hline
\end{tabular}

Berdasarkan Tabel di atas ada 19 Sekolah jenjang SMP Sesumatera Selatan yang berpartisispasi dalam mengisi kuisioner ini dengan presentase yang berbeda-beda.

Tabel 1. Media Pembelajaran

\begin{tabular}{|l|r|r|r|r|}
\hline & & & & \multicolumn{2}{c|}{$\begin{array}{c}\text { Cumulative } \\
\text { Percent }\end{array}$} \\
\hline Valid Google Clasroom & 73 & 73.0 & 73.0 & 73.0 \\
& 8 & 8.0 & 8.0 & 81.0 \\
\hline
\end{tabular}




\section{Journal of Software Engineering Ampera}

Vol. 2, No. 3, October 2021 e-ISSN: 2775-2488

https://journal-computing.org/index.php/journal-sea/index

\begin{tabular}{|l|r|r|r|r|}
\hline Zoom & 7 & 7.0 & 7.0 & 88.0 \\
Edmodo & 12 & 12.0 & 12.0 & 100.0 \\
Total & 100 & 100.0 & 100.0 & \\
\hline
\end{tabular}

Untuk media pembelajaran online yang di gunakan Siswa SMP berdasarkan table di atas paling banyak yaitu menggunakan Google Classroom yang presentasenya sebesar $73 \%$ dan lainnya ada edmodo sebesar $12 \%$, google meet $8 \%$ dan Zoom 7\%.

\subsection{Hasil Perhitungan SUS}

\section{a. Perhitungan SUS Score pada Media Pembelajaran Google Classroom}

Tabel6. Nilai SUS Score media pembelajaran google classroom

\begin{tabular}{|l|r|r|r|r|r|r|r|r|r|r|r|r|r|}
\hline \multirow{2}{*}{$\begin{array}{c}\text { Respon } \\
\text { den }\end{array}$} & $\begin{array}{r}\text { learnabil } \\
\text { ity }\end{array}$ & \multicolumn{2}{|c|}{$\begin{array}{c}\text { efficien } \\
\text { cy }\end{array}$} & \multicolumn{2}{|c|}{$\begin{array}{c}\text { Memorabi } \\
\text { lity }\end{array}$} & \multicolumn{2}{|c|}{ errors } & \multicolumn{2}{c|}{$\begin{array}{c}\text { satisfacti } \\
\text { on }\end{array}$} & \multirow{2}{*}{$\begin{array}{c}\text { SUS Raw } \\
\text { Score }\end{array}$} & $\begin{array}{c}\text { SUS Final } \\
\text { Score }\end{array}$ \\
\hline R1 & 4 & 1 & 3 & 2 & 3 & 2 & 4 & 1 & 4 & 2 & 30 & 75 \\
\hline R2 & 4 & 2 & 5 & 1 & 4 & 1 & 5 & 2 & 3 & 1 & 34 & 85 \\
\hline R3 & 3 & 1 & 3 & 2 & 4 & 2 & 3 & 1 & 3 & 2 & 28 & 70 \\
\hline R4 & 3 & 1 & 3 & 1 & 5 & 2 & 3 & 1 & 5 & 2 & 32 & 80 \\
\hline R5 & 3 & 2 & 3 & 2 & 3 & 1 & 4 & 2 & 4 & 1 & 29 & 72,5 \\
\hline R6 & 4 & 1 & 3 & 2 & 4 & 1 & 4 & 1 & 2 & 1 & 31 & 77,5 \\
\hline R7 & 4 & 1 & 5 & 3 & 5 & 1 & 5 & 1 & 4 & 2 & 35 & 87,5 \\
\hline R8 & 4 & 1 & 3 & 2 & 4 & 1 & 3 & 2 & 4 & 1 & 31 & 77,5 \\
\hline R9 & 5 & 2 & 3 & 3 & 5 & 1 & 4 & 2 & 4 & 1 & 32 & 80 \\
\hline R10 & 3 & 1 & 4 & 1 & 3 & 1 & 3 & 1 & 2 & 1 & 30 & 75 \\
\hline R11 & 4 & 1 & 2 & 1 & 4 & 2 & 5 & 1 & 3 & 2 & 31 & 77,5 \\
\hline R12 & 5 & 2 & 4 & 3 & 4 & 2 & 4 & 2 & 3 & 2 & 29 & 72,5 \\
\hline R13 & 5 & 1 & 3 & 2 & 3 & 2 & 5 & 2 & 2 & 1 & 30 & 75 \\
\hline R14 & 5 & 3 & 3 & 1 & 4 & 2 & 3 & 1 & 5 & 1 & 32 & 80 \\
\hline R15 & 5 & 2 & 3 & 2 & 4 & 2 & 4 & 1 & 3 & 1 & 31 & 77,5 \\
\hline R16 & 4 & 2 & 3 & 2 & 5 & 1 & 4 & 2 & 1 & 2 & 28 & 70 \\
\hline R17 & 5 & 2 & 4 & 2 & 4 & 1 & 5 & 2 & 4 & 1 & 34 & 85 \\
\hline R18 & 5 & 2 & 2 & 2 & 3 & 3 & 3 & 3 & 2 & 2 & 23 & 57,5 \\
\hline
\end{tabular}




\section{Journal of Software Engineering Ampera}

Vol. 2, No. 3, October 2021 e-ISSN: 2775-2488

https://journal-computing.org/index.php/journal-sea/index

\begin{tabular}{|c|c|c|c|c|c|c|c|c|c|c|c|c|}
\hline R19 & 4 & 2 & 1 & 2 & 5 & 1 & 5 & 2 & 4 & 2 & 30 & 75 \\
\hline R20 & 4 & 2 & 4 & 1 & 4 & 3 & 3 & 1 & 4 & 2 & 30 & 75 \\
\hline R21 & 5 & 3 & 2 & 1 & 3 & 2 & 5 & 1 & 4 & 2 & 30 & 75 \\
\hline $\mathrm{R} 22$ & 4 & 3 & 3 & 2 & 3 & 3 & 4 & 2 & 1 & 2 & 23 & 57,5 \\
\hline R23 & 5 & 1 & 3 & 2 & 4 & 1 & 5 & 1 & 4 & 2 & 34 & 85 \\
\hline R24 & 4 & 2 & 2 & 1 & 4 & 2 & 3 & 1 & 5 & 1 & 31 & 77,5 \\
\hline R25 & 5 & 1 & 3 & 1 & 5 & 2 & 4 & 2 & 3 & 1 & 33 & 82,5 \\
\hline R26 & 3 & 3 & 4 & 1 & 4 & 4 & 3 & 3 & 2 & 5 & 20 & 50 \\
\hline R27 & 4 & 5 & 3 & 5 & 5 & 5 & 5 & 5 & 3 & 5 & 15 & 37,5 \\
\hline R28 & 3 & 3 & 3 & 3 & 3 & 3 & 3 & 3 & 3 & 3 & 20 & 50 \\
\hline R29 & 4 & 2 & 4 & 1 & 4 & 1 & 3 & 2 & 3 & 2 & 30 & 75 \\
\hline R30 & 1 & 1 & 1 & 1 & 1 & 1 & 1 & 1 & 1 & 1 & 20 & 50 \\
\hline R31 & 5 & 1 & 5 & 1 & 5 & 1 & 5 & 1 & 1 & 5 & 32 & 80 \\
\hline R32 & 3 & 2 & 4 & 1 & 4 & 1 & 5 & 1 & 5 & 1 & 35 & 87,5 \\
\hline R33 & 3 & 5 & 1 & 3 & 5 & 3 & 2 & 1 & 2 & 5 & 16 & 40 \\
\hline R34 & 1 & 1 & 5 & 1 & 1 & 5 & 1 & 1 & 1 & 5 & 16 & 40 \\
\hline R35 & 5 & 1 & 5 & 5 & 5 & 5 & 5 & 1 & 5 & 4 & 29 & 72,5 \\
\hline R36 & 5 & 1 & 5 & 1 & 5 & 1 & 1 & 1 & 5 & 5 & 32 & 80 \\
\hline R37 & 5 & 5 & 3 & 5 & 3 & 5 & 4 & 5 & 1 & 5 & 11 & 27,5 \\
\hline R38 & 5 & 4 & 5 & 1 & 4 & 5 & 5 & 1 & 1 & 5 & 24 & 60 \\
\hline R39 & 5 & 2 & 5 & 5 & 5 & 3 & 5 & 3 & 1 & 5 & 23 & 57,5 \\
\hline R40 & 1 & 5 & 5 & 5 & 2 & 1 & 5 & 3 & 2 & 3 & 18 & 45 \\
\hline R41 & 3 & 2 & 5 & 1 & 4 & 5 & 3 & 5 & 4 & 4 & 22 & 55 \\
\hline R42 & 5 & 4 & 5 & 1 & 5 & 5 & 5 & 1 & 1 & 5 & 25 & 62,5 \\
\hline R43 & 5 & 5 & 5 & 5 & 5 & 5 & 2 & 5 & 5 & 5 & 17 & 42,5 \\
\hline R44 & 5 & 1 & 5 & 2 & 5 & 2 & 5 & 1 & 3 & 4 & 33 & 82,5 \\
\hline R45 & 1 & 5 & 1 & 5 & 5 & 5 & 5 & 5 & 1 & 5 & 8 & 20 \\
\hline R46 & 5 & 1 & 5 & 5 & 5 & 1 & 5 & 1 & 5 & 5 & 32 & 80 \\
\hline R47 & 5 & 1 & 5 & 5 & 5 & 5 & 5 & 5 & 5 & 5 & 24 & 60 \\
\hline R48 & 4 & 5 & 2 & 3 & 1 & 5 & 4 & 4 & 1 & 4 & 11 & 27,5 \\
\hline R49 & 4 & 3 & 3 & 4 & 5 & 3 & 2 & 3 & 2 & 4 & 19 & 47,5 \\
\hline R50 & 4 & 3 & 4 & 4 & 4 & 4 & 4 & 4 & 3 & 3 & 21 & 52,5 \\
\hline R51 & 3 & 3 & 4 & 3 & 3 & 3 & 4 & 3 & 3 & 4 & 21 & 52,5 \\
\hline R52 & 3 & 3 & 3 & 3 & 4 & 4 & 5 & 3 & 3 & 5 & 20 & 50 \\
\hline
\end{tabular}




\section{Journal of Software Engineering Ampera}

Vol. 2, No. 3, October 2021 e-ISSN: 2775-2488

https://journal-computing.org/index.php/journal-sea/index

\begin{tabular}{|c|c|c|c|c|c|c|c|c|c|c|c|c|}
\hline R53 & 5 & 3 & 3 & 5 & 5 & 1 & 3 & 3 & 4 & 3 & 25 & 62,5 \\
\hline R54 & 5 & 3 & 3 & 1 & 5 & 1 & 5 & 2 & 5 & 4 & 32 & 80 \\
\hline R55 & 3 & 5 & 2 & 2 & 4 & 4 & 4 & 3 & 2 & 3 & 18 & 45 \\
\hline R56 & 1 & 2 & 3 & 4 & 5 & 1 & 2 & 3 & 4 & 5 & 20 & 50 \\
\hline R57 & 5 & 5 & 2 & 5 & 5 & 5 & 5 & 5 & 2 & 5 & 14 & 35 \\
\hline R58 & 4 & 2 & 3 & 5 & 3 & 4 & 4 & 2 & 1 & 3 & 19 & 47,5 \\
\hline R59 & 1 & 3 & 2 & 3 & 2 & 5 & 1 & 2 & 1 & 5 & 9 & 22,5 \\
\hline R60 & 3 & 3 & 3 & 3 & 3 & 3 & 3 & 3 & 3 & 3 & 20 & 50 \\
\hline R61 & 2 & 3 & 3 & 3 & 3 & 2 & 3 & 3 & 3 & 3 & 20 & 50 \\
\hline R62 & 5 & 2 & 4 & 3 & 4 & 2 & 4 & 4 & 4 & 4 & 26 & 65 \\
\hline R63 & 4 & 2 & 4 & 1 & 5 & 1 & 3 & 1 & 4 & 5 & 30 & 75 \\
\hline R64 & 5 & 1 & 5 & 1 & 5 & 1 & 5 & 1 & 4 & 5 & 35 & 87,5 \\
\hline R65 & 3 & 4 & 3 & 5 & 4 & 4 & 3 & 2 & 2 & 3 & 17 & 42,5 \\
\hline R66 & 3 & 3 & 3 & 3 & 3 & 3 & 3 & 3 & 3 & 3 & 20 & 50 \\
\hline R67 & 5 & 1 & 5 & 1 & 5 & 1 & 5 & 3 & 5 & 3 & 36 & 90 \\
\hline R68 & 5 & 1 & 5 & 1 & 1 & 1 & 5 & 1 & 5 & 5 & 32 & 80 \\
\hline R69 & 5 & 1 & 5 & 5 & 5 & 1 & 5 & 1 & 5 & 5 & 32 & 80 \\
\hline R70 & 5 & 2 & 3 & 5 & 5 & 5 & 1 & 5 & 5 & 5 & 17 & 42,5 \\
\hline R71 & 5 & 1 & 5 & 3 & 5 & 2 & 5 & 1 & 5 & 4 & 34 & 85 \\
\hline R72 & 5 & 2 & 5 & 1 & 4 & 4 & 3 & 3 & 4 & 4 & 27 & 67,5 \\
\hline R73 & 4 & 4 & 5 & 5 & 4 & 4 & 5 & 5 & 5 & 4 & 21 & 52,5 \\
\hline & $\begin{array}{r}28 \\
9 \\
\end{array}$ & $\begin{array}{r}17 \\
2 \\
\end{array}$ & $\begin{array}{r}25 \\
8 \\
\end{array}$ & $\begin{array}{r}18 \\
9 \\
\end{array}$ & $\begin{array}{r}29 \\
1 \\
\end{array}$ & $\begin{array}{r}18 \\
8 \\
\end{array}$ & $\begin{array}{r}27 \\
9 \\
\end{array}$ & $\begin{array}{r}16 \\
6 \\
\end{array}$ & $\begin{array}{r}23 \\
1 \\
\end{array}$ & $\begin{array}{r}23 \\
4 \\
\end{array}$ & & \\
\hline & \multicolumn{11}{|c|}{ Average Nilai SUS Score media pembelajaran google classroom } & 63,7 \\
\hline
\end{tabular}

Dari table di atas dapat di simpulkan bahwa Nilai SUS Score media pembelajaran google classroom bernilai rata-rata : 63,7 hasil ini termasuk dalam kategori marginal high dengan grade $\mathrm{D}$, hasil ini menandakan bahwa keseluruhan responden atau dari 73 responden menyatakan media pembelajaran ini perlu perbaikan dimana dalam satisfaction mendapatkan nilai total 231:234 hanya selisih 3 yaitu yang artinya responden belum puas dalam menggunakan media pembelajaran dan harus belejar terlebih dahulu dalam menggunakan media pembelajaran tersebut. 


\section{Journal of Software Engineering Ampera}

Vol. 2, No. 3, October 2021 e-ISSN: 2775-2488

https://journal-computing.org/index.php/journal-sea/index

\section{b. Perhitungan SUS Score pada Media Pembelajaran Google Meet}

Tabel 7. Nilai SUS Score media pembelajaran google meet

\begin{tabular}{|c|c|c|c|c|c|c|c|c|c|c|c|c|}
\hline \multirow{2}{*}{$\begin{array}{c}\text { Respon } \\
\text { den }\end{array}$} & \multicolumn{2}{|c|}{$\begin{array}{l}\text { learnabil } \\
\text { ity }\end{array}$} & \multicolumn{2}{|c|}{$\begin{array}{c}\text { efficien } \\
\text { cy }\end{array}$} & \multicolumn{2}{|c|}{$\begin{array}{l}\text { memorabi } \\
\text { lity }\end{array}$} & \multicolumn{2}{|c|}{ errors } & \multicolumn{2}{|c|}{$\begin{array}{l}\text { satisfacti } \\
\text { on }\end{array}$} & \multirow{2}{*}{$\begin{array}{l}\text { SUS Raw } \\
\text { Score }\end{array}$} & \multirow{2}{*}{$\begin{array}{l}\text { SUS Final } \\
\text { Score }\end{array}$} \\
\hline & P1 & P2 & $\begin{array}{l}P \\
3 \\
\end{array}$ & $\begin{array}{l}P \\
4 \\
\end{array}$ & P5 & P6 & $\begin{array}{l}P \\
7 \\
\end{array}$ & $\begin{array}{l}P \\
8\end{array}$ & $\begin{array}{l}P \\
9 \\
\end{array}$ & P10 & & \\
\hline R74 & 5 & 2 & 4 & 1 & 5 & 1 & 3 & 1 & 3 & 3 & 24 & 60 \\
\hline R75 & 5 & 1 & 4 & 1 & 4 & 2 & 4 & 1 & 1 & 2 & 23 & 57,5 \\
\hline R76 & 5 & 2 & 5 & 2 & 3 & 3 & 4 & 3 & 4 & 1 & 24 & 60 \\
\hline R77 & 5 & 2 & 3 & 2 & 5 & 2 & 5 & 3 & 4 & 3 & 24 & 60 \\
\hline R78 & 5 & 5 & 5 & 5 & 5 & 5 & 5 & 5 & 5 & 5 & 20 & 50 \\
\hline R79 & 5 & 1 & 1 & 5 & 1 & 2 & 5 & 2 & 5 & 2 & 25 & 62,5 \\
\hline R80 & 4 & 4 & 4 & 5 & 4 & 4 & 5 & 3 & 4 & 5 & 20 & 50 \\
\hline R81 & 3 & 3 & 3 & 3 & 3 & 3 & 3 & 3 & 4 & 3 & 17 & 42,5 \\
\hline & 37 & 20 & $\begin{array}{l}2 \\
9\end{array}$ & $\begin{array}{l}2 \\
4\end{array}$ & 30 & 22 & $\begin{array}{l}3 \\
4\end{array}$ & $\begin{array}{l}2 \\
1\end{array}$ & $\begin{array}{l}3 \\
0\end{array}$ & 24 & & \\
\hline & & Ave & se 1 & ilai $S$ & $5 \mathrm{Scc}$ & med & per & nbel & jarar & goog & eeet & 55,313 \\
\hline
\end{tabular}

Dari tabel di atas dapat di simpulkan media pembelajaran google meet mendapatkan nilai SUS Score 55,3 dengan grade E yanng artinya dari 8 responden menyatakan bahwa media google meet ini masih perlu banyak perbaikan. bisa di lihat dari tabel di atas perbandingannya antara total pervariabel itu sangat sedikit seperti pada efficiency, perbandingannya 29:24 hanya selisih 5 yang artinya siswa masih banyak membutuhkan bantuan dalam menggunakan media ini. Kemudian pada tingkat satisfaction juga perlu di perbaiki yang perbandingannya 30:24 hanya selisih 6 saja yang artinya siswa perlu belajar dalam penggunaan media tersebut.

\section{c. Perhitungan SUS Score pada Media Pembelajaran Zoom}

Tabel 8. Nilai SUS Score media pembelajaran Zoom

\begin{tabular}{|c|c|c|c|c|c|c|c|c|c|c|c|c|}
\hline \multirow{2}{*}{$\begin{array}{c}\text { Respon } \\
\text { den }\end{array}$} & \multicolumn{2}{|c|}{$\begin{array}{c}\text { learnabil } \\
\text { ity }\end{array}$} & \multicolumn{2}{|c|}{$\begin{array}{c}\text { efficien } \\
\text { cy }\end{array}$} & \multicolumn{2}{|c|}{$\begin{array}{c}\text { memorabi } \\
\text { lity }\end{array}$} & \multicolumn{2}{|c|}{ errors } & \multicolumn{2}{|c|}{$\begin{array}{c}\text { satisfacti } \\
\text { on }\end{array}$} & \multirow{2}{*}{$\begin{array}{l}\text { SUS Raw } \\
\text { Score }\end{array}$} & \multirow{2}{*}{$\begin{array}{l}\text { SUS Final } \\
\text { Score }\end{array}$} \\
\hline & P1 & $\mathrm{P} 2$ & $\begin{array}{l}P \\
3 \\
\end{array}$ & $\begin{array}{l}P \\
4 \\
\end{array}$ & P5 & P6 & $\begin{array}{l}P \\
7\end{array}$ & $\begin{array}{l}P \\
8\end{array}$ & $\begin{array}{l}P \\
9 \\
\end{array}$ & P10 & & \\
\hline R82 & 5 & 3 & 3 & 1 & 4 & 2 & 5 & 1 & 5 & 2 & 33 & 82,5 \\
\hline R83 & 5 & 3 & 4 & 2 & 3 & 2 & 5 & 1 & 4 & 3 & 30 & 75 \\
\hline R84 & 4 & 1 & 3 & 1 & 3 & 1 & 5 & 2 & 3 & 2 & 31 & 77,5 \\
\hline
\end{tabular}




\section{Journal of Software Engineering Ampera}

Vol. 2, No. 3, October 2021 e-ISSN: 2775-2488

https://journal-computing.org/index.php/journal-sea/index

\begin{tabular}{|c|c|c|c|c|c|c|c|c|c|c|c|c|}
\hline R85 & 4 & 3 & 4 & 2 & 4 & 3 & 3 & 2 & 4 & 3 & 26 & 65 \\
\hline R86 & 5 & 2 & 4 & 2 & 2 & 2 & 4 & 3 & 5 & 2 & 29 & 72,5 \\
\hline R87 & 4 & 2 & 4 & 2 & 4 & 2 & 4 & 2 & 4 & 3 & 29 & 72,5 \\
\hline R88 & 5 & 5 & 1 & 2 & 4 & 5 & 4 & 1 & 2 & 4 & 19 & 47,5 \\
\hline & 32 & 19 & $\begin{array}{l}2 \\
3\end{array}$ & $\begin{array}{l}1 \\
2\end{array}$ & 24 & 17 & $\begin{array}{l}3 \\
0\end{array}$ & $\begin{array}{l}1 \\
2\end{array}$ & $\begin{array}{l}2 \\
7\end{array}$ & 19 & & \\
\hline & \multicolumn{11}{|c|}{ Average Nilai SUS Score media pembelajaran Zoom } & 70,35714 \\
\hline
\end{tabular}

Pada media pembelajaran Zoom mendapatkan nilai SUS sebesar 70,4 dengan grade $C$ yang artinya dari 7 responden yang memilih media pembelajaran Zoom menyatakan media pembelajaran ini baik di gunakan karena perbandingan dalam variabelnya selisih cukup banyak.

\section{a. Perhitungan SUS Score pada Media Pembelajaran Google Classroom}

Tabel 9. Nilai SUS Score media pembelajaran Edmodo

\begin{tabular}{|c|c|c|c|c|c|c|c|c|c|c|c|c|}
\hline \multirow{2}{*}{$\begin{array}{c}\text { Respon } \\
\text { den }\end{array}$} & \multicolumn{2}{|c|}{$\begin{array}{c}\text { learnabil } \\
\text { ity }\end{array}$} & \multicolumn{2}{|c|}{$\begin{array}{c}\text { efficien } \\
\text { cy }\end{array}$} & \multicolumn{2}{|c|}{$\begin{array}{l}\text { memorabi } \\
\text { lity }\end{array}$} & \multicolumn{2}{|c|}{ errors } & \multicolumn{2}{|c|}{$\begin{array}{l}\text { satisfacti } \\
\text { on }\end{array}$} & \multirow{2}{*}{$\begin{array}{l}\text { SUS Raw } \\
\text { Score }\end{array}$} & \multirow{2}{*}{$\begin{array}{l}\text { SUS Final } \\
\text { Score }\end{array}$} \\
\hline & P1 & P2 & $\begin{array}{l}P \\
3 \\
\end{array}$ & $\begin{array}{l}\mathrm{P} \\
4 \\
\end{array}$ & P5 & P6 & $\begin{array}{l}\mathrm{P} \\
7 \\
\end{array}$ & $\begin{array}{l} \\
8 \\
\end{array}$ & $\begin{array}{l}P \\
9 \\
\end{array}$ & P10 & & \\
\hline R90 & 5 & 3 & 4 & 1 & 3 & 2 & 4 & 1 & 3 & 1 & 31 & 77,5 \\
\hline R91 & 5 & 1 & 5 & 1 & 3 & 1 & 5 & 1 & 5 & 3 & 36 & 90 \\
\hline R92 & 5 & 1 & 4 & 1 & 5 & 1 & 5 & 1 & 3 & 1 & 37 & 92,5 \\
\hline R93 & 4 & 1 & 5 & 1 & 5 & 3 & 5 & 2 & 2 & 3 & 31 & 77,5 \\
\hline R94 & 5 & 3 & 3 & 1 & 3 & 2 & 4 & 2 & 3 & 2 & 28 & 70 \\
\hline R95 & 3 & 2 & 4 & 2 & 3 & 2 & 3 & 2 & 5 & 2 & 28 & 70 \\
\hline R96 & 4 & 2 & 5 & 3 & 5 & 1 & 4 & 2 & 3 & 2 & 31 & 77,5 \\
\hline R97 & 3 & 1 & 2 & 2 & 5 & 2 & 4 & 1 & 4 & 2 & 30 & 75 \\
\hline R98 & 5 & 3 & 5 & 1 & 5 & 1 & 3 & 1 & 2 & 2 & 32 & 80 \\
\hline R99 & 5 & 1 & 3 & 1 & 4 & 1 & 4 & 1 & 4 & 1 & 35 & 87,5 \\
\hline R100 & 5 & 2 & 1 & 2 & 5 & 2 & 4 & 2 & 3 & 1 & 29 & 72,5 \\
\hline & 49 & 20 & $\begin{array}{l}4 \\
1\end{array}$ & $\begin{array}{l}1 \\
6\end{array}$ & 46 & 18 & $\begin{array}{l}4 \\
5\end{array}$ & $\begin{array}{l}1 \\
6\end{array}$ & $\begin{array}{l}3 \\
7\end{array}$ & 20 & & \\
\hline & & & rage & Nilai & SUS Sc & re me & dia $p$ & $\mathrm{emb}$ & lajar & $\mathrm{an} \mathrm{Edn}$ & do & 79,0909 \\
\hline
\end{tabular}

Pada media pembelajaran Edmodo mendapatkan nilai SUS sebesar 78,5 dengan grade C (acceptable), yang artinya dari 12 responden menyatakan bahwa Edmodo merupakan media yang baik atau layak di gunakan dalam 


\section{Journal of Software Engineering Ampera}

Vol. 2, No. 3, October 2021 e-ISSN: 2775-2488

https://journal-computing.org/index.php/journal-sea/index

pembelajaran online dan bernilai di atas rata-rata bisa di lihat pada perbandingan dalam variabelnya cukup banyak selisihnya.

\subsection{Hasil Uji Validitas}

Dengan mengevaluasi korelasi antara skor item dan skor total, uji validitas dilakukan untuk memastikan bahwa instrumen penelitian memberikan hasil yang sesuai dengan tujuannya. Menggunakan software aplikasi Spss Statistics 16.

Hasil dari pengujian tersebut dimana semua variabel yang diuji telah dimasukkan dengan ketentuan signifikansi ( $p$-value).apabila nilai signifikansi < 0,05 maka disimpulkan item tersebut valid.dan apabia nilai signifikansi > 0,05 maka berkesimpulan item tersebut tidak valid.

Tabel 10. hasil uji validitas

\begin{tabular}{|c|c|c|c|c|c|c|c|c|c|c|c|c|}
\hline & & P1 & P2 & P3 & P4 & P5 & P6 & P7 & P8 & P9 & P10 & Total \\
\hline \multirow[t]{3}{*}{ P1 } & $\begin{array}{l}\text { Pearson } \\
\text { Correlation }\end{array}$ & 1 & -.155 & $.253^{*}$ & -.081 & $.328^{* *}$ & -.128 & $.432^{* *}$ & -.112 & $.301^{* *}$ & -.068 & $.312^{* *}$ \\
\hline & $\begin{array}{l}\text { Sig. (2- } \\
\text { tailed) }\end{array}$ & & .123 & .011 & .424 & .001 & 205 & .000 & .266 & .002 & .503 & .002 \\
\hline & $\mathrm{N}$ & 100 & 100 & 100 & 100 & 100 & 100 & 100 & 100 & 100 & 100 & 10 \\
\hline \multirow[t]{3}{*}{ P2 } & $\begin{array}{l}\text { Pearson } \\
\text { Correlation }\end{array}$ & -.155 & 1 & $-.227^{*}$ & $.405^{* *}$ & $\mid-.031$ & $.580^{* *}$ & -.025 & $.516^{* *}$ & $281^{* *}$ & $.372^{* *}$ & $.493^{* *}$ \\
\hline & $\begin{array}{l}\text { Sig. (2- } \\
\text { tailed) }\end{array}$ & .123 & & .023 & .000 & .758 & .000 & .802 & .000 & .005 & .000 & .000 \\
\hline & $\mathrm{N}$ & 100 & 100 & 100 & 100 & 100 & 100 & 100 & 100 & 100 & 100 & 0 \\
\hline \multirow[t]{3}{*}{ P3 } & $\begin{array}{l}\text { Pearson } \\
\text { Correlation }\end{array}$ & $.253^{*}$ & $-.227^{*}$ & 1 & -.044 & . 185 & -.052 & 187 & -.018 & $.228^{*}$ & $.260^{* *}$ & $.344^{* *}$ \\
\hline & $\begin{array}{l}\text { Sig. (2- } \\
\text { tailed) }\end{array}$ & .011 & .023 & & 661 & .066 & .609 & .062 & .863 & .023 & .009 & .0 \\
\hline & $\mathrm{N}$ & 100 & 100 & 100 & 100 & 100 & 100 & 100 & 100 & 100 & 100 & 100 \\
\hline \multirow[t]{3}{*}{ P4 } & $\begin{array}{l}\text { Pearson } \\
\text { Correlation }\end{array}$ & -.081 & $.405^{* *}$ & -.044 & 1 & . 108 & $.424^{* *}$ & .074 & $.593^{* *}$ & .024 & $.443^{* *}$ & $.667^{* *}$ \\
\hline & $\begin{array}{l}\text { Sig. (2- } \\
\text { tailed) }\end{array}$ & .424 & .000 & .661 & & .284 & .000 & .467 & .000 & .813 & .000 & .000 \\
\hline & $\mathrm{N}$ & 100 & 100 & 100 & 100 & 100 & 100 & 100 & 100 & 100 & 100 & 100 \\
\hline P5 & $\begin{array}{l}\text { Pearson } \\
\text { Correlation }\end{array}$ & $328^{* *}$ & -.031 & .185 & .108 & 1 & -.062 & |.171. & .035 & . 184 & .191. & $.400^{* *}$ \\
\hline
\end{tabular}


https://journal-computing.org/index.php/journal-sea/index

\begin{tabular}{|c|c|c|c|c|c|c|c|c|c|c|c|c|}
\hline & $\begin{array}{l}\text { Sig. (2- } \\
\text { tailed) }\end{array}$ & .001 & .758 & .066 & .284 & & .537 & .088 & .730 & .067 & .057 & .000 \\
\hline & $\mathrm{N}$ & 100 & 100 & 100 & 100 & 100 & 100 & 100 & 100 & 100 & 100 & 100 \\
\hline \multirow[t]{3}{*}{ P6 } & $\begin{array}{l}\text { Pearson } \\
\text { Correlation }\end{array}$ & -.128 & $.580^{* *}$ & -.052 & $.424^{* *}$ & -.062 & 1 & -.129 & $584^{* *}$ & $272^{* *}$ & $.544^{* *}$ & $.581^{* *}$ \\
\hline & $\begin{array}{l}\text { Sig. (2- } \\
\text { tailed) }\end{array}$ & .205 & .000 & .609 & .000 & .537 & & 199 & .000 & .006 & .000 & .000 \\
\hline & $\mathrm{N}$ & 100 & 100 & 100 & 100 & 100 & 100 & 100 & 100 & 100 & 100 & 100 \\
\hline \multirow[t]{3}{*}{ P7 } & $\begin{array}{l}\text { Pearson } \\
\text { Correlation }\end{array}$ & $.432^{* *}$ & -.025 & .187. & .074 & 171. & -.129 & 1 & -.041 & .121 & -.037 & $.318^{* *}$ \\
\hline & $\begin{array}{l}\text { Sig. (2- } \\
\text { tailed) }\end{array}$ & .000 & .802 & .062 & .467 & .088 & |199. & & .682 & .229 & .715 & .001 \\
\hline & $\mathrm{N}$ & 100 & 100 & 100 & 100 & 100 & 100 & 100 & 100 & 100 & 100 & 100 \\
\hline \multirow[t]{3}{*}{ P8 } & $\begin{array}{l}\text { Pearson } \\
\text { Correlation }\end{array}$ & -.112 & $.516^{* *}$ & -.018 & $.593^{* *}$ & .035 & $.584^{* *}$ & -.041 & 1 & -.009 & $.395^{* *}$ & $.661^{* *}$ \\
\hline & $\begin{array}{l}\text { Sig. (2- } \\
\text { tailed) }\end{array}$ & .266 & .000 & .863 & .000 & .730 & .000 & .682 & & 931 & .000 & .000 \\
\hline & $\mathrm{N}$ & 100 & 100 & 100 & 100 & 100 & 100 & 100 & 100 & 100 & 100 & 100 \\
\hline \multirow[t]{3}{*}{ P9 } & $\begin{array}{l}\text { Pearson } \\
\text { Correlation }\end{array}$ & $.301^{* *}$ & $281^{* *}$ & $.228^{*}$ & .024 & 184 & $.272^{* *}$ & |121. & -.009 & 1 & -.072 & $.235^{*}$ \\
\hline & $\begin{array}{l}\text { Sig. (2- } \\
\text { tailed) }\end{array}$ & .002 & .005 & .023 & 813 & .067 & .006 & .229. & .931 & & .474 & .019. \\
\hline & $\mathrm{N}$ & 100 & 100 & 100 & 100 & 100 & 100 & 100 & 100 & 100 & 100 & 100 \\
\hline \multirow[t]{3}{*}{ P10 } & $\begin{array}{l}\text { Pearson } \\
\text { Correlation }\end{array}$ & $-.068 \mid$ & $.372^{* *}$ & $260^{* *}$ & $.443^{* *}$ & 191 & $.544^{* *}$ & -.037 & $.395^{* *}$ & -.072 & 1 & $.680^{* *}$ \\
\hline & $\begin{array}{l}\text { Sig. (2- } \\
\text { tailed) }\end{array}$ & .503 & .000 & .009 & .000 & .057 & .000 & .715 & .000 & .474 & & \\
\hline & $\mathrm{N}$ & 100 & 100 & 100 & 100 & 100 & 100 & 100 & 100 & 100 & 100 & 100 \\
\hline \multirow[t]{3}{*}{ Total } & $\begin{array}{l}\text { Pearson } \\
\text { Correlation }\end{array}$ & $.312^{* *}$ & $.493^{* *}$ & $.344^{* *}$ & $.667^{* *}$ & $.400^{* *}$ & $.581^{* *}$ & $.318^{* *}$ & $.661^{* *}$ & $.235^{*}$ & $.680^{* *}$ & 1 \\
\hline & $\begin{array}{l}\text { Sig. (2- } \\
\text { tailed) }\end{array}$ & .002 & .000 & .000 & .000 & .000 & .000 & .001. & .000 & .019 & .000 & \\
\hline & $\mathrm{N}$ & 100 & 100 & 100 & 100 & 100 & 100 & 100 & 100 & 100 & 100 & \\
\hline
\end{tabular}




\section{Journal of Software Engineering Ampera}

Vol. 2, No. 3, October 2021 e-ISSN: 2775-2488

https://journal-computing.org/index.php/journal-sea/index

\subsection{Hasil Uji Reliabilitas}

Tabel 2. Uji Reliabilitas

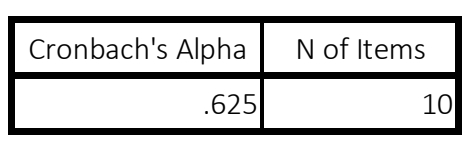

Alpha Cronbach adalah tes statistik. Jika nilai Cronbach Alpha suatu variabel lebih dari 0,6, dikatakan dapat diandalkan (Nunnally, 1960). Tabel di atas dapat digunakan untuk mencari jumlah nilai reliabilitas yang lebih besar dari 0,625. Hasilnya, data dapat disimpulkan dapat diandalkan, dapat dipercaya, dan konsisten.

\section{KESIMPULAN}

Berdasarkan pembahasan yang telah di jelaskan di atas dapat di simpulkan bahwa System Usability Scale (SUS) dapat di jadikan alat ukur untuk penilaian media yang terukur dan terstruktur secara akurat. Dimana pada System Usability Scale (SUS) memiliki rumus untuk menentukan hasil penilaian dan memiliki standar penilian yang beragam seperti yang di perlihatkan ketika melakukan penilaian pada media pembelajaran online dengan berbagai macam media yang di gunakan siswa. Dari hasil kuisioner yang telah di sebar dan di analisis oleh peneliti maka di dapat kesimpulan bahwa media yang paling banyak di gunakan siswa SMP di Sumatera Selatan pada masa pandemi covid -19 ini adalah Google Classroom dimana dari 100 sampel yang memilih media google classroom ini sebanyak 73 Siswa dengan penilaian medianya mendapatkan skor 63,6644 dengan grade D, hasil ini menandakan bahwa keseluruhan responden atau dari 73 responden menyatakan media pembelajaran ini perlu perbaikan dimana dalam satisfaction mendapatkan nilai total 231:234 hanya selisih 3 yaitu yang artinya responden belum puas dalam menggunakan media pembelajaran dan harus belajar terlebih dahulu dalam menggunakan media pembelajaran tersebut. Tetapi Google Classroom ini bukan media yang mendapatkan nilai skor terbaik. Menurut penelitian di atas media yang mendapatkan nilai skor terbaik yaitu media pembelajaran Edmodo mendapatkan nilai SUS sebesar 78,5 dengan grade C (acceptable), yang artinya dari 12 responden menyatakan bahwa Edmodo merupakan media yang baik atau layak di gunakan dalam pembelajaran online dan bernilai di atas rata-rata bisa di lihat pada perbandingan dalam variabelnya 


\section{Journal of Software Engineering Ampera}

Vol. 2, No. 3, October 2021 e-ISSN: 2775-2488

https://journal-computing.org/index.php/journal-sea/index

cukup banyak selisihnya. Sedangkan untuk media pembelajaran Zoommendapatkan nilai skor 70,4 dengan grade $\mathrm{C}$ dari 7 Responden dan Media Pembelajaran Google Meet mendapatkan nilai Skor SUS 55,3 dengan grade E dari 8 responden.

\section{DAFTAR PUSTAKA}

adam, \& toufik. (2019). peran media pembelajaran . pendidikan , 79.

Aswati, M. S. (2017). tegnologi informasi. penegrtian tegnologi .

budiman. (2017). tegnologi informasi pendidikan. pendidikan .

Budiman, H. (2017). PERAN TEKNOLOGI INFORMASI DAN KOMUNIKASI DALAM. Al-Tadzkiyyah: Jurnal Pendidikan Islam, Volume 8 No. I 2017, 34-35.

catherineyang94. (2017, marc 25). Pengertian dan Pentingnya Audit TI dan E-

Cash. Dipetik january 22, 2020, dari CATHER: https://catherineyang94.wordpress.com/2017/03/25/pengertian -dan-pentingnya-audit-ti-dan-e-cash-tp1-qa/

Debora, Y. (2020, september). tirto.id. Dipetik oktober 25, 2020, dari Riwayat Kasus Corona di Indonesia, dari Maret hingga September 2020: https://tirto.id/riwayat-kasus-corona-di-indonesia-dari-marethingga-september-2020-f4d6

Dengen, N., \& Hatta, H. R. (2009). Perancangan Sistem Informasi Terpadu. Jurnal Informatika Mulawarman , 48.

huda. (2017). pengertian media. penegrtian media.

Media, R. (2021). KUMPULAN PENGERTIAN. Dipetik 2021, dari https://www.kumpulanpengertian.com/2020/12/pengertiananalisis-menurut-para-ahli.html

Miftah, Z., \& sari, i. p. (2020). ANALISIS SISTEM PEMBELAJARAN DARING. Miftah, Z. \& Sari, I. P. / Reseacrh and Development Journal of Education, 41.

rusman. (2018). peran media pembelejaran. pendidikan , 164.

Sasmita, G. G. (2015). BAB II_GIAN GUSLI SASMITA_TI'15.pdf. Dipetik 2021, http://repository.ump.ac.id/5837/3/BAB\%20II_GIAN\%20GUSLI\% 20SASMITA_TI\%2715.pdf 